\title{
VII. An examination of St. Pierre's hypothesis respecting the cause of the tides, which, in opposition to the received theory, attributes them to supposed periodical effusions of the polar ices. Read before the Askesian Society November 5, 1799
}

\section{Samuel Woods Esq.}

To cite this article: Samuel Woods Esq. (1800) VII. An examination of St. Pierre's hypothesis respecting the cause of the tides, which, in opposition to the received theory, attributes them to supposed periodical effusions of the polar ices. Read before the Askesian Society November 5, 1799 , Philosophical Magazine Series 1, 8:30, 134-147, DOI: $10.1080 / 14786440008562620$

To link to this article: http://dx.doi.org/10.1080/14786440008562620

\section{Published online: 18 May 2009.}

\section{Submit your article to this journal $\sqsubset$}

Џ Article views: 2 
lens for five minutes, that the thermometer might affume the temperature of its fituation. The refult was as follows :

The lens covered $o^{\prime}$ Open - I
No. 3. Here, in one minute, the

$\left.64^{\circ}\right\}^{\circ}$ thermometer received

$176\}$ I12 degrees of heat, which came with the coloured part of the folar fpectrum, and were refracted to a focus; fo that, if the coloured rays themfelves are not of a heat-making nature, they are at leaft accompanied with rays that have a power of heating bodies, and are fubject to certain laws of refraction, which cannot dificr much from thofe affecting light.

[To be contisued.]

VII. An Examination of St. PIER RE's Hypotbefis refpecting the Caufe of the Tides, wbich, in oppofition to the received Theory, attributes them to fupposed periodical Effufions of the Polar lees. By Sa mue Woods, Efq. Read before the Afkefian Society November 5, 1799.

$\mathrm{T}$

$\mathrm{HE}$ tides are two periodical motions actuating the ocean (called the flux and refux, or ebb and flow), which fucceed each other alternately at an interval of about fix hours; the period of a flux and reflux being, upon an average, i 2 hours 24 minutes, the double of which, 24 hours 48 minutes, correfponds to that of a lunar day, or the time elapfing between the moon's paffing a meridian and coming to it again. Thefe alternate elevations and depreffions of the ocean fo exactly correfpond with the courfe of the fun and moon, as to time and quantity, that the influence of thofe luminaries has in all ages been confidered as the caufe of their production; but it was referved for modern times to afcertain the principle of their laws, and to calculate, with precifion, the effects produced by the different fituations of the fun and moon, and the proportions of their power. This principle is no other than gravitation. It is evident that, if the earth were entirely fluid and quiefcent, its particles, by their mutual gravity, would form the whole mafs into a perfect fphere: now, if any power be fuppofed to act on all the particles of this fphere 
with equal force, and in parallel directions, the whole mafs wonld be moved together without experiencing any alteration in its figure. But this is not the cafe with refpect to the moon's action on our globe : the power of gravity diminithes as the fquare of the diltance increafes, and therefore the waters (at Z, Plate V. fig. 1.) on the fide of the earth (A,B,C,D) next the moon $(M)$, are more attracted by the moon than the. central parts of the carth $(\mathrm{O})$, and the central parts more attracted than the waters on the oppofite fide (at $n$ ) ; and therefore the diftance between the earth's centre and the waters on its furface under and oppofite to the moon will be increafed. For, fuppofe three bodies in the fame line (H,O,D), if they are all equally attracted by any power (as M), they will, all move towards it with equal rapidity, their mutual diftances continuing the fame; but if the attraction of this power (M) is unequal, the body moft forcibly attracted will move fafteft, and their reciprocal diftances will be proportionally increafed : thus, the power of gravitation acting unequally on the bodies $(\mathrm{H}, \mathrm{O}, \mathrm{D})$, the diftance of the firtt $(H)$ from the fecond $(\mathrm{O})$, and of the fecond from the third (D), will be increafed in proportion to the difference of the gravitating power at the diftance of the three bodies (H,O,D) refpectively: now, fuppofe a number of bodies. $(A B C D)$ placed round the centre $(O)$ fo as to form a fluid ring, unequally attracted by fome power (M), the parts neareft and furtheft $\left(H_{1}\right.$ and $D$ ) from this power will have their diftance from the centre $(\mathrm{O})$ increafed, while the fides of this ring $(B$ and $F$ ); beirg nearly equidiftant from the power $(\mathrm{M})$, the centre $(\mathrm{O})$ will not recede, but rather approach the centre $(0)$, and form an ellipfis ( $(n L I z N)$. To apply this reafoning to the cafe under confideration, while the earth, by its gravity, tends toward the moon, the water directly below her will fwell and rife gradually; the water on the oppofite fide will recede from the centre (or, more properly, the centre will advance), and rife, or appear to rife, while the water at the fides is depreffed, and falls below the former level: hence, as the earth revolves on its axis from the moon to the moon again in 24 hours 50 minutes, there will be two tides of ebb and two of flood in that period. In con- 
Philo. Mag. Pl . V. Vol. VIII.
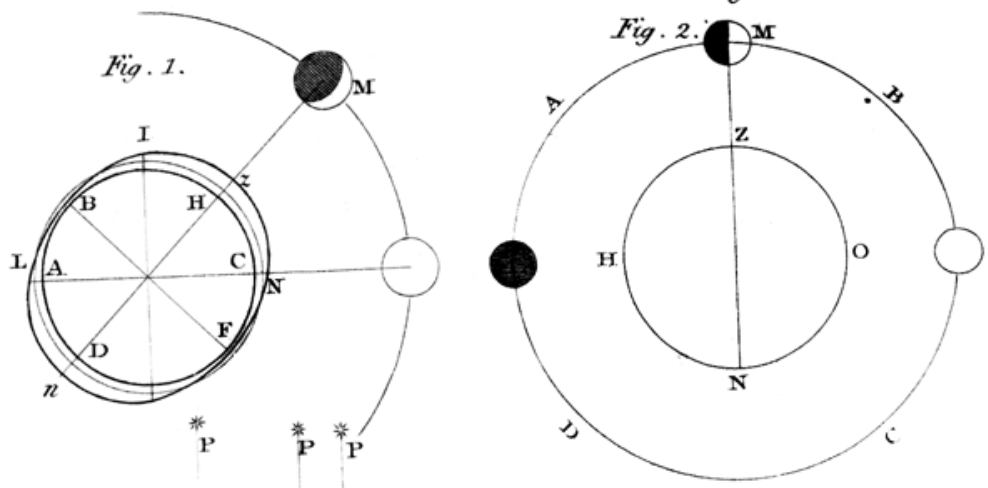

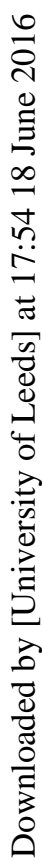
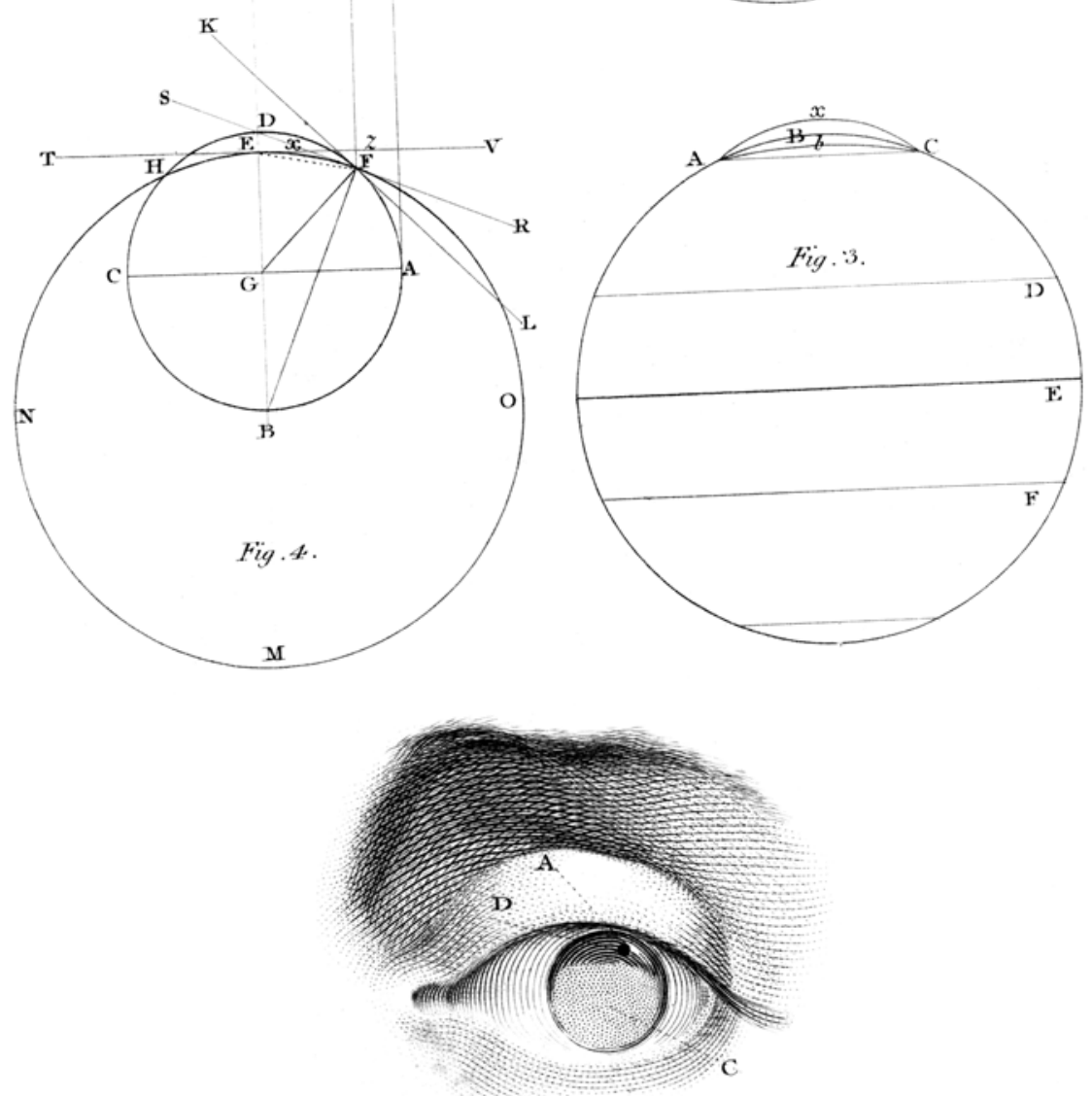
fequence of the earth's motion on her axis, the molt elevated part of the water is carried beyond the moon in the direction of the rotation, and continues to rife after it has paffed directly under the moon, not attaining its greateft elevation till it: his got about half a quadrant further. It continues alfo to defcend, after it has paffed at $90^{\circ}$ diftance from the point below the moon; to a like diftance of about half aquadrant; and therefore in open feas, where the water flows freely, the time of high water does not exactly coincide with the time of the moon's coming to the meridian, but is fome time after. Befides, the tides do not always anfwer to the fame diftance of the moon from the meridian, fince they are variounly affected by the fun's action, which brings them on fooner when the moon is in her firft and third quarters; and keeps them back later when the is in her fecond and fourth: becaufe, in the former cafe, the tide raifed by the fun alone would be earlier than the tide raifed by the moon: in the latter cafe, later.

We have hicherto confidered the moon as the principal agent in producing tides, but it is obvious that the inequality of the fun's action muft produce a fimilar effect; fo that, in reality, there are two tides every natural day occafioned by the fun, as well as two tides every lunar day occafioned by the moon, and fubject to the fame laws: on account, however, of the fun's immenfe diftance, his action is confiderablyinferior to that of the moon. By comparingthe fpring and neap tides at the mouth of then, belew Briftol, Sir Ifac Newton calculates the popotion of the moon's force to the fun's as 9 to 2 nearly: Dr. Horley, in his edition of the Principia, eftimates it as 5,0469 to $\mathrm{r}$; and, confidering the elevation of the waters by this force as an effect fimilar the elevation of the equatorial above the polar parts of the earth, it will be found that the moon is capable of producing an elevation of about ten feet, the fun of about two feet; which correfponds pretty nearly to experience.

In order to underftand the caufe of fpring and neap tides, we muft confider, that the moon, revolving round the earth in an elliptic orbit, approaches nearer and recedes further from it, than her mean diftance, in every revolution or lunar month. When nearef; her attraction is ftrongeit; and vice 
verfa: when both luminaries are in the equator, and the moon in perigeo, the tides rife higheft, particularly at oppofition and conjunction: at the change, when the attractive forces of the fun and moon are combined, the tide is raifed to a greater height: at the full, when the moon raifes the tide under and oppofite to her, the fun, acting in the fame line, raifes the tides under and oppofite to him, whence their conjunct effect is the fame as at the change, and in both cafes occafions what we call fpring tides: but at the quarters, the fun's action diminithes the effect of the moon's action, fo that they rife a little under and oppofite the fun, and fall as much under and oppofite the moon, thefe two luminaries acting obliquely on each other, and producing what is called neap tides *.

The fpring tides, however, do not happen precifely at the full and change of the moon, nor the neap tides at the quarters, but about two days later. In this, as in many other cafes, the effests are not greateft, or leaft, when the immediate influence of the caufe is greateft or leaft: as, for inftance, the greateft heat of fummer is not at the time of the folftice, but fome weeks after; and if the actions of the fun and moon fhould be fuddenly fufpended, the tides would continue for fome time in their ufual courfe. The variations of the moon's diftance from the earth produce a fenfible difference in the tides. When the moon approaches the earth, her action on every part increafes, and the differences of her action increafe in a higher proportion as the moon's diftances decreafe. According to Sir. Ifaac Newton, the tides increafe as the cubes of the diftances decreafe; fo that the moon, at half her diftance, would produce tides eight times as. great. The fun being nearer the earth in winter than in fummer, the fpring tides are highert, and the neap tides loweft, about the time of the equinoxes, a little after the autumnal and before the vernal; and, on the contrary, the fpring tides loweft and the neap tides higheft at the folftices, when the

- In Fig. 2. Plate V. HZON reprefents the earth; ABCD the moon's orbit. At the full and change, the fun and moon act in the fame line S.P : at the quarters, the fun's influence in the line SOH counteracts that of the moon adting in the direction $\mathrm{MZN}$, and produces neap tides.

VaL. VIII. 
fun is molt diftant from the equator. When the moon is in the equator, the tides are equally high in both parts of the lunar day; but as the moon declines towards either pole, the tides are alternately higher and lower at places having north or fouth latitude: while the fun is in the northern figns, the greater of the two diurnal tides in our climates is that arifing from the moon above the horizon: when the fun is in the fouthein figns, the greateft is that arifng from the moon below the horizon. Thus the evening tides in fummer are obferved to exceed the morning tides, and in winter the morning tides exceed the evening tides: the difference at Brifol is found to be 15 inches, at Plymouth i2. It would be fill greater, but that a fluid always retains an impreffed motion for fome time, and confequently the preceding tides always affect thofe that follow.

If the earth were covered all over with the fea to a great depth, the tides would be regularly fubfervient to thefe laws; but various caufes combine to produce a great diverfity of effect, according to the peculiar fituation and circumftances of places, thoals, fords, and ftraits : thus, a flow and imperceptible motion of a large body of water, fuppofe two miles deep, will be fufficient to elevate its furface ten or twelve feet in a tide's time; whereas, if the fame quantity of water is forced through a narrow channel forty or fifty fathoms deèp, it produces a very rapid ftream, and of courfe the tide is found to fet ftrongeft in thofeplaces where the fea grows narroweft, the fame quantity of water being conftrained to pafs through a fmaller paffage, as in the ftraits between Portland and Cape la Hogue in Normandy; and it would be fill more fo between Dwer and Calais, if the tide coming round the iffand did not check it.

The hoalnefs of the fea and the intercurrent continents are the reafons why the tides in the open ocean rife but to very inconfiderable heights, when compared to what they do in wide-mouthed rivers opening in the direction of the ftream of the tide; and that high water is fome hours after the moon's appulfe to the meridian, as it is obferved upon all the weftern coatt of Europe and Africa from Ireland to the Cape of Good Hope; in all which a fouth-weft moon makes high 
high water; and the fame is faid to be the cafe on the weftern coaft of America : fo that tides happen to different places at all diftances of the moon from the meridian, and confequently at all hours of the day.

To allow the tides their full motion, the fpace in which they are produced ought to extend from eaft to weft $90^{\circ}$ at leaft; fuch being the diftance between the places moft raifed and depreffed by the moon's influence. Hence it appears that fuch tides can only be produced in large oceans, and why thofe of the Pacific exceed thofe of the Atlantic ocean : hence alfo it is obvious why the tides in the torrid zone between Africa and America, where the ocean is narrower, are exceeded by thofe of the temperate zones on either fide : and hence we may comprehend why the tides are fo fmall in illands at a great diftance from the hores, fince the water cannot rife on one fhore without defcending on the other: fo that at the intermediate iflands it muft continue at a mean height between its elevations on thofe fhores.

The tide produced on the weftern coaft of Europe correfponds to this theory. Thus, it is high water on the weftern coafts of Ireland, Spain, and Portugal, about the third hour after the moon has paffed the meridian; from thence it flows into the adjacent channels, as it finds the eafieft paffage. One current, for example, runs up by the fouth of England, and another by the north of Scotland; taking confiderable time to move all this way, and occafioning high water fooner in the places at which it firt arrives, and begins to fall at thefe places while the current is proceeding to others further diftant in its courfe. On its return it is unable to raife a tide, becaufe the water runs fafter off than it rolurns, till, by the propagation of a new tide from the ocean, the current is ftopt, and begins to rife again. The tide propagated by the moon in the German ocean, when the is three hours paft the meridian, takes twelve hours to come from thence to London bridge; fo that, when it is high water there, a new tide has already attained its height in the ocean, and in fome intermediate place it muft be low water at the fame time. When the tide runs over thoals, and flows upon flat fhores, the water 
is elevated to a greater height than in open and deep oceans that have fteep banks, becaufe the force of its motion is not broken upon level thores till the water has attained a greater height. If a place communicates with two oceans, or by two different openings with the fame ocean, one of which affords an eafier and readier paffage than the other, two tides may arrive at this place in different times, which, interfering together, may produce a great variety of phænomena.

At feveral places it is high water three hours befare the moon comes to the meridian; but that tide which the moon drives, as it were, before her, is only the tide oppofite to that produced by her when nine hours paft the oppofite meridian.

It would be tedious to enumerate all the particular folutions eafily deducible from thefe dootrines : as, why lakes and feas, fuch as the Cafpian and the Mediterranean, the Euxine and the Baltic, have little or no fenfible tides; fince, having no communication, or being connected by very narrow inlets with the great ocean, they cannot receive or difcharge water fufficient to alter their furface fenfibly. In general, when the time of high water at any place is mentioned, it is to be underftood on the days of new and full moon: the times of high water in any place fall at nearly the fame hours after a period of about fifteen days, or between one fpring tide and another.

This theory, however, is not without objections and diffculties; which has encouraged a Frenchman of fome eminence, 'St. Pierre, to frame a new and fingular hypothefis, afcribing all the phænomena of the tides to the periodical effufions of the polar ices. I hall firt mention the moft material facts and confiderations which appear to militate againft the common theory, as Atated by St. Pierre; and I thall then endeavour to explain the theory he has fubftituted (which it has coft me fome pains to collect, abtract, and arrange), as nearly as poffible in a literal tranflation of his own language.

IT is faid that, if the moon acted by her attraction, her influence muft extend to the Mediterranean, the Baltic, the Caf- 
pian, and the vaft lakes of North America, in fome degsec at leaft; but all thefe have no ferfible tides*. This tranquillity renders her attraction liable to fufpicion; and we thall, perhaps, find that the greateft part of the tides in the ocean have nothing more than an apparent relation either her influence or ther courfe.

The phafes of the moon do not correfpond all over the globe with the movements of the feas. On our coafts the flux and reflux follow the moon rather than her real motion: in various places they are fubject to different laws, which obliged Newton to admit (chap. 25.) " that in the periodical return of the tides there muft be fome other mixed caufe, hitherto undifoovered."

The currents and tides in the vicinity of the polar circle come from the pole, as appears from the teftimony of Fred. Martens, who afferts, that the currents amidft the ices fet in towards the fouth; but adds, that he can ftate nothing with certainty refpecting the flux and reflux of the tides.- Ioyage towards the Nortb Pale, I671.

Henry Ellis obferved that the tides in Hudfon's bay came from the north, and were accelerated as the latitude increafed. It is impoffible thefe tides thould come from the line or the Atlantic. He afcribes them to a pretended communication with the South fea. At Waigat's ftraits thefe north tides run at the rate of eight or ten leagues an hour. Ine compares them to the nuice of a mill.-Voyage to Hudfon's Bay, 1746 .

Linfcotten, in 1594 , made nearly the fame remarks, and obferves that in Waigat's ftraits the water was only brackifh. He fays the tides come from the eaft with great velocity, bringing with them large iflands of ice.

W. Barents (1595) confirms this account.

All thefe effects can be produced by nothing elfe thin the effution of ices furrounding the pole. Thefe ices, which melt and flow with fuch rapidity in the northern parts of America and Europe about the months of July and Auguft,

- The Cafpian fea is about 860 miles long, and, in one place, 260 miles broad : there are ftrong currents, but no tides.

There is no regular flux and reflux in the Baltic.

In fome particular foots of the Mediterranean there is a fmall tide. 
greatly contribite to our high equinoctial tides; and when thefe effufions ceafe in October, our tides begin to diminith.

If the tides depended on the action of the fun and moon on the equator, they ought to be much more confiderable towards the focus of their movements than any where elfe. But this is contrary to fact (Dampier fays). From Cape Blanc, from the third to $30^{\circ}$ fouth lat. the flux and reflux of the fea does not exceed two feet. The tides in the Eaft Indies rife not above a foot; near the poles they rife 20 or 25 feet.

In the road of the ifland Maffafuero $\left(33^{\circ} 46^{\prime}\right.$ fouth lat. $80^{\circ} 22^{\prime}$ weft long.) the fea runs twelve hours north, and then flows back twelve hours fouth : its tides, therefore, run towards the line.-Byron, April 1765 .

At Englifh Creek, on the coaft of New Britain ( $5^{\circ}$ fouth lat. $15^{\circ}$ weft long.) the tide has a flux and reflux once in 24 hours.-Carteret, Aug. 1767.

At the Bay of Inles, in New Zealand ( $35^{\circ}$ fouth lat.), the tides fet in from the fouth.-Cook, Dec. 1769 .

At Endeavour River, in New Holland, neither the flood nor ebb tides were confiderable, excepting once in 24 hours. - June, rijo.

At Chriftmas Harbour, in Kerguelen's Land, the flood came from the fouth-eaft, running two knots an hour.Cook, Dec. I776. It appears to have been regular and diurnal, $i$. e. a tide of twelve hours. The tide rifes and falls about four feet.

At Otaheite the tides feldom rife more than twelve or fourteen inches; and it is high water nearly at noon, as well at the quarters as at the full and change of the moon.-Cook, Dec. 7777. It is evident, from a table of thefe tides for 26 days, that there was but one tide a day; and this, during the whole time, was at its mean height between $r I$ and $r$. Thefe tides, therefore, can have no relation to the phafes of the moon.

Let us now take a curfory view of the effects produced by the tides in the northern part of the South fea. At the entrance of Nootka it is high water, on the days of new and full moon, at twenty minutes paft twelve: the perpendicular rife and fall eight feet nine inches; which is to be underftood of 
the day tides, and thofe which happen two or three days after the full and change. The night tides rife nearly two feet higher.-Cook, April I778. Thefe femidiurnal tides differ from ours in taking place at the fame hour, and exhibiting no fenfible rife till the fecond or third day after the full moon: all which is perfectly inexplicable on the lunar hypothefis.

Thefe northern tides of the South fea, remarked in April, become, in higher latitudes, ftronger in May, and ftill ftronger in June; which cannot be referred to the moon's courfe then paffing into the fouthern hemifphere, but muft be afcribed to the fun's courfe paffing into the northern hemifphere, and proceeding, as its heat increafes, to fufe the ices of the north pole : befides, the direction of thefe northern tides towards the line conftitutes a complete confirmation that they derive their origin from the pole.

At the entrance of Cook's River there was a ftrong tide fetting out of the inlet at the rate of three or four knots an hour: higher up in the inlet, at a place four leagues broad, the tide ran with prodigious violence at the rate of five knots an hour. Here the marks of a river difplayed themfelves, the water proving confiderably frefher.-Cook, May $\mathrm{x} 778$.

What Cook calls a river, is nothing but a real northern nuice, through which the polar effufions are difcharged into the ocean. Middleton (Voyage to Hudfon's Bay, 174I and $\mathrm{I} 742$ ) found, between lat. $65^{\circ}$ and $66^{\circ}$, a confiderable inlet running wet, which he calls Wager's River; and, after repeated trials of the tides for three weeks, found the flood conftantly coming from the eaft. This is another of the northern fuices.

In Karakakooa Bay, Sandwich Iflands, the tides are very regular, ebbing and flowing fix hours each alternately.Clerke, Marcb 1779 .

At the town of St. Peter and Paul, in Kamfchatka, the tides are very regular every twelve hours.-Clerke, Oa. 1779 .

Mr. Wales (Introduction to Cook's laft Voyage) acknowledges that the tides obferved in the middle of the great Pacific ocean fall thort full two-thirds of what might have been expected from calculation.

The courfe of the tides towards the equator in the South 


\section{Examination of St. Pierre's Hypotbelis}

fea; their retardations and accelerations on thefe fhores; their directions, fometimes ealtward, fometimes weftward, according to the monfoons; finally, their elevation, which increales in proportion as we approach the poles, and diminifues in proportion to the diftances from it, even between the tropics, demonftrate that their focus is not under the line. The caufe of their motions depends not on the attraction or preflure of the fun and moon on that part of the ocean, for their forces would undoubtedly aet there with the greateft energy, and in periods as regular as the courfe of the two luminaries.

Why, then, are the tides between the tropics fo feeble and fo much retarded under the direct influence of the moon?

Why does the moon, by her attraction, give us two tides every 24 hours in the A.tlantic ocean, and produce only one in many parts of the South fea, which is incomparably broader?

Why do the tides take place there conftantly at the fame hours, and rife to a regular height almoft all the year round?

Why do fome rife at the quarters juit the fame as at the full and change?

Why are they always ftronger as you approach the poles, and frequently fet in toward the line, contrary to the principle of lunar impulfion?

Thefe problems, which it is impoffible to explain by the lunar theory, admit an eafy folution on the hypothefis of the alternate fufion of the polar ices.

Such are the mot material objections adduced to invalidate the lunar theory. How far they are conclufive, fhall be left to future inveltigation.

But St. Pierre is not content with demolifhing the old ftrneture; he has judged proper to ereet a new one; and a fair expofition of this fyftem will enable us to determine, by comparifon, to which we fhall give our fuffrage.

It is well known that Sir Ifaac Newton and Caffini differed in their opinion refpecting the figure of the earth : the former concciving it to be an oblate fpheroid, flattened at the poles; we latter contending it muft be oblong, or elongated at the 
poles. To afcertain this point, fome of the moft celebrated mathematicians of Europe were appointed to determine, by actual meafurement, the length of a degree both at the equator and at the pole. They found that the polar degrees exceeded the equatorial, and concluded they muft confequently be parts of a larger circle, and, of courfe, that the earth was flattened at the poles. This was univerfally confidered as decifive of the queftion, till the genius of our Frenchman detected a grofs and palpable error, in the calculation, which had efcaped their accurate knowledge and penetration : but, as the elongation of the poles conftitutes a leading feature in the new theory, I thall give it a more detailed examination.

This polar elongation, as he conceives, is fupported by four direct and pofitive proofs:which he lays the greateit frefs, and upon which he has ftaked his reputation; the $2 d$, atmofpherical ; the $3 \mathrm{~d}$, nautical; the $4^{\text {th }}$, aftronomical : of all which in order.

The ift, or geometrical proof, is what he calls a demonfration founded on the meafurement of the earth, and admitting the polar degrees to exceed the equatorial: here follows the demonftration: If you place a degree of the meridian at the polar circle on a degree of the fame meridian at the equator, the firlt degree, which meafures 57,422 fathoms, will exceed the $2 \mathrm{~d}$, which is 56,748 fathoms, by 674 ; confequently, if you apply the arc of the meridian contained within the polar circle, being $47^{\circ}$; to an arc of $47^{\circ}$ of the fame meridian at the equator, it would produce a confiderable protuberance, its degrees being greater.

To render this more apparent, let us always fuppofe that the profile of the earth, at the poles, is an arc of a circle containing $47^{\circ}$; is it not evident, if you trace a curve on the infide of this arc, as the academicians do when they flatten the earth at the poles, that it muft be finaller than the arc within which it is defcribed, being contained in it? And the more this curve is fiattened the fmaller it becomes. Of confequence, the $47^{\circ}$ of this entire curve will be individually fmaller than the $47^{\circ}$ of the containing arc. But as the degrees of the polar curve exceed thofe of the arc of a circle, it muft follow that the whole curve is of greater extent Vou. VIII. 


\section{Examination of St. Pierre's Hypotbefis}

than the arc of a circle: now to be of greater extent it muft be more protuberant : the polar curve, of confequence, forms a lengthened ellipfis. Q. E. D.*

It muft be acknowledged that this demonftration is very perfpicuous and convincing. How the molt celebrated academicians and mathematicians, for nearly half a century, could have overlooked a propofition fo plain and fimple, can only be afcribed, in the opinion of St. Pierre, to their obftinate and inveterate prejudices. He purfues his victory in a frain of vain and indecent exultation, which would difhonour a more refpectable caufe; but, perhaps, a little attention will induce us to doubt at leaft whether the charge of grofs ignorance may not, with juftice, be retorted on their accufer.

It would have been indeed extraordinary, if men of fcience had been abfurd enough to imagine that a larger arc might be included in a lefs ; but they might fuppofe, with propriety and juftice, that the fmaller arc of a larger circle can be included in the larger arc of a fmaller circle, which, in the prefent inftance, appears to be the cafe. In meafuring a degree on the meridian, a certain fpot is fixed upon, where the elevation of the polar ftar is taken by a quadrant; from this fpot they proceed in a direct line north, till the quadrant indicates an additional elevation of one degree. In proportion as this degree conftitutes a part of a larger or fmaller

* Let $x$, Fig. 3. Plate Y. be the unknown arc of the meridian, comprehended above the arfic circle $A B C$; and let DEF be the arc of the fame meridian, compiehended between the tropics; thefe two arcs are each $4 \%^{\circ}$. According to our antonomers, a degrce at the polar circle is greater by 674 fathoms than a degree of the fame meridian near the equator; the arc $x$ therefore excesds, in extent, the arc DEF by $674 \times 47$, or 31,678 fithoms $=1.2 \frac{1}{3}$ leagues. The queftion to be determined is, whether this unknown polar arc $x$ is contained within the circle in the curve A BC, or comcides with it, as A B C, or falls without its circumfercnce, as $A \times C$. The arc $x$ cannot be contained within the circle, as $A .4 C$, for it world then be evidently fomaller than the arc $A B C$; and the more this curve $A b C$ is flattened, the lefs, will be its extezt, as it vill approach pearer and nearer to the ftraight line $\mathrm{AC}$; peither can it coinçide with the arc $A B C$, for it exceeds it $12 \frac{2}{3}$ leagues. It nulf belong, therefore, to a curve filing without the circle, as $A x \mathrm{C}$. The grlobe of the earth, therefore, is lengthened at the poles, fince degrees of the meridian are greater bere than at the equator.

circle, 
circle, a greater or lefs portion of ground will be paffed over before the defired elevation is obferved; and the meafures ment of this ground unequivocally decides wheth $r$ this degree is part of a larger or fmaller circle. In this cale the meafurement is admitted, but the conclufion denied. St. Pierre feens to have fuppofed, that the academicians divided the polar arc into 47 parts, and then meafured one of thefe parts : a thing impracticable and ridiculous: The fact is, that the polar arc, which, if the earth were a perfect fphere, would contain $47^{\circ}$, does not actually contain fo many, but perhaps about $46^{\circ}$ of a larger circle; and if the polar degrees are parts of a larger circle, as they certainly are, it is demonftrably evident that the real arc muft be contained within the fpherical arc, and, confequently, that the earth is flattened at the poles *.

[To be continued.]

* Let the circle A B C D, Fig. 4. reprefent the earth as a fphere, and let $P$ reprefent the polar ftar, having no fenfible parallax. Draw the diameter $B D$, prolonging it to $P$; draw the tranlverfe diameter $C A$, the tangent $A P$, and the line F P, parallel to A P ; bifeet the quadrant A D equally at $F$; draw the tangent $K \mathrm{~L}$ perpendicular to the radius $\mathrm{GF}$, and with the radius $B F$ dufcribe the circle $E O M N$, and let the fegment $\mathrm{HEF}$ reprefent the earth flattened at the pole; draw the tangent $S R$ to the circle $\mathrm{EOMN}$, perpendicular to the radius $\mathrm{BF}$. An oblerver at $\mathrm{A}$ wi perceive the polar ftar $\mathbf{P}$ in the herizon; an obferver at $D$ or $E$ will per ceive it in the zenith, or at an elcvation of $90^{\circ}$. If the earth be a fphere the tangent $\mathrm{KL}$ will be the horizon to an obferver at $\mathrm{F}$, and the angle of elevation PFK is, by conftruction, $45^{\circ}$; but if the earth is not a fphere, but fiattened towards the pole, as in the fegment $\mathrm{HEF}$, the tangent $\mathrm{SR}$ will be the horizon to an obferver at F, and of courfe the angle PF S will be the angle of elevation: Now, the angle EGF is by conftruction $45^{\circ}$, nfequently, the <FG B $35^{\circ}$, and the angles GBF and GFB each $22^{\circ} 3^{\circ}$ : Draw the dotted line EF. Now the triangle B E F is an itofceles iriangle, and the angle $\mathrm{GBF}$ being found $=22^{\circ} 30^{\prime}$, it follows that the angles $B$ E F and B FE are each $78^{\circ} 45^{\prime}$, and the $<$ S F B being a right angle, the $<\mathrm{SFE}$ is $90^{\circ}-7^{\circ}-45^{\circ}=11^{\circ} 15^{\circ}$. At $\mathrm{E}$ draw the tangent $\mathrm{TV}$, and, for the fame reafon, the $\angle \mathrm{VEF}=11^{\circ} \times 5^{\prime}$; and confequently the $\angle E x F=157^{\circ}+30^{\prime}$, and the $\angle V x F=2.2^{\circ} 30^{\circ}$. Now the $\angle F Z F$ is a right an fle, therefore the angle $\mathrm{PF} S=180^{\circ}-90^{\circ}-22330^{\circ}$, or $67^{\circ} 30^{\prime}$. The difference, thereforë, between the elevation ar $\mathbf{E}$ and at $\mathbf{F}$ will be $90-67,30=223^{\circ}$, but the difference between the elevation at $\mathrm{F}$ and $\mathrm{D}$ will be $45^{\circ}$; whence it is evident that a larger meafurement of ground will be included in a degree in proportion as H F.F is the fegment of a larger or fmaller circle. 